Maria Kjos Fonn

Forfatter

Foto: Håvard Bøhm

\title{
Hverdagen nedlagt
}

\section{Sykehusreformer gjør psykiatriske pasienter ekstra sårbare. Er behandlere i helsevesenet gode nok til å ivareta pasientene under flytting og nedleggelse av avde- linger?}

Det er en grunnleggende kjensgjerning for de fleste av oss at store endringer i jobb, bosted eller omgangskrets skaper utrygghet. Dessverre har jeg sett på nært hold at det ikke alltid blir tatt høyde for dette når det dreier seg om virkelig sårbare pasienter og nedleggelse av psykiatriske avdelinger.

Jeg kjente en mann med en tyngre psykisk bør i livet enn de fleste. Et halvt liv inn og ut av psykiatrien gjorde at det var her han hadde sine fleste referanser. Psykiatrien var bakgrunn for humoren, kjærlighetshistoriene - og traumene. Altfor mange belteleggelser gjorde at han ikke kunne bruke sikkerhetsbelte når han kjørte bil.

Da han ble innlagt for 30. gang, spøkte han med at han ville ha bløtkake og gullklokke. Det tragikomiske rommer en viktig sannhet - psykiatrien var stedet han alltid vendte tilbake til. Han var en veteran, og om innleggelsen ikke var noe å feire, var det noe å ta hensyn til.

Man er, av mange gode grunner, redd for at pasientene skal bli institusjonalisert og vil unngå at sykehuset blir et hjem snarere enn et behandlingssted. Like fullt kan forsettene om hvordan ting burde være skygge for hvordan ting faktisk er. For mange pasienter med et ekstremt ustabilt liv blir avdelingen et fast holdepunkt - hvor smertefullt det enn kan være å være inn- lagt. Og for ham jeg kjente, var den en kilde til sosialt liv, omsorg og nærhet, som ellers var begrenset.

Det er forståelig at flytting innebærer et stressmoment også for helsepersonell. En flytteperiode vil naturligvis være kaotisk - man skifter arbeidsplass, rutiner går i oppløsning, pasientene er stresset. Nettopp derfor bør ansatte i psykiatrien være ekstra bevisst: Vil personalets stressnivå smitte over på pasientene? Hvordan kan man sørge for at de blir møtt på angsten $\sin$, ivaretatt og tatt på alvor i en periode preget av ytre kaos?

Uro, stress og irritasjon over endring kan prege friske folk. For virkelig syke, utsatte pasienter kan det å miste en trygg havn være et spørsmål om liv eller død.

For ham jeg kjente, ble det en krise at hans faste psykiatriske avdeling skulle legges ned. Det var utenkelig for ham å flytte til en annen avdeling - altså ble han sendt hjem. Han opplevde at ingen tok angsten hans på alvor - han fikk jo valget: Flytte til et nytt, ukjent sykehus langt borte eller dra hjem.

Kort tid etterpå tok han en overdose med reseptbelagte medisiner. Neste uke én til. Og neste uke enda en. Han ble sendt til somatisk avdeling for å pumpes, gang på gang. Han fortalte meg at en pleier etter enda en overdose kalte ham idiot. Jeg har et bedre ord: desperat.

Erfarent helsepersonell lot ikke til å forstå budskapet bak overdosene: Behovet for kontakt med et system han følte hadde sviktet ham. År med samme psykiatriske avdeling å vende tilbake til gjorde denne til en trygg havn. Å oppsøke en annen ville være utrygt og fremmedgjørende. Men den somatiske avdelingen hadde ikke flyttet, og den eneste måten å bli innlagt der var å skade seg selv fysisk.

Det er ingen som gang på gang går gjennom den enorme fysiske påkjenningen en overdose er, med pumping og oppkast, for å gjøre livet vanskelig for overarbeidet helsepersonell. Paradoksalt nok tror jeg det lå en form for selvoppholdelsesdrift i selvskadingen - han trengte omsorg fra andre, å bli møtt på at han hadde det uutholdelig vanskelig.

Han var ikke den mest språksterke. Vi snakket mye, beskrivelsen av livssituasjonen hans kom stykkevis og delt. Men den var ikke til å misforstå hvis man lyttet.

En dag fikk jeg vite at han var $d \varnothing d$. Om det var med fullt overlegg eller om den siste overdosen bare ble én for mye for kroppen hans, vet jeg ikke. Det jeg vet, er at ingen møtte ham i den enormt sårbare situasjonen at hans faste avdeling flyttet. Som lekperson vet jeg ikke hvilket tiltak som ville vært best. Det jeg vet, er at han opplevde at tiltakene glimret med sitt fravær.

Ingen enkeltmennesker har skyld i at slikt skjer. Jeg oppfatter det først og fremst som et systemproblem, et system som til tider er for fragmentert til å hjelpe dem som det egentlig er til for. «Noen» burde riktignok ha tatt ansvar, men ingen har full oversikt over at ingen andre gjør det. Er du ikke på listen, eksisterer du ikke.

Dette er først og fremst en historie å bli svært nedslått av. Men også en historie å lære av.

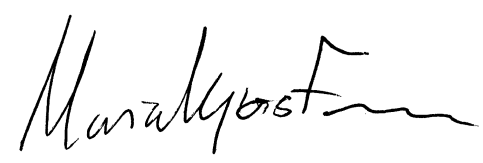

